\title{
Numerical Study on the Effect of Liquid Injection in Hepatic Microwave Ablation
}

\author{
Zhen TIAN, Qun NAN ${ }^{*}$, Xiao-hui NIE, Tong DONG and Rui-rui \\ WANG
}

Life Science and Biomedical Engineering, Beijing University of Technology Beijing, China

*nanqun@bjut.edu.cn

${ }^{*}$ Corresponding author

Keywords: Liquid Injection, Microwave Ablation, Lesion Size, Numerical Simulation.

\begin{abstract}
Purpose: The aim of this study is to research the impact of the liquid injection in hepatic microwave ablation (MWA) by using finite element method (FEM).

Methods: We used the finite element method to simulate the MWA without liquid injection, with $0.9 \%$ NACL (saline) and with ethanol in turn. At the frequency of $2.45 \mathrm{GHz}$ and the duration time of $300 \mathrm{~s}$, we set the microwave powers at $40 \mathrm{~W}, 60 \mathrm{~W}$ and $80 \mathrm{~W}$. The volume of the saline and ethanol was $10 \mathrm{ml}$.

Results: Compared to the lesion size of the group without liquid injection, the lesion size with saline was larger in the area range from $19.42 \%$ to $60.54 \%$, and the ablation with ethanol was larger in area range from $15.66 \%$ to $58.69 \%$ as the microwave power increasing.

Conclusions: MWA with liquid injection can expand the lesion size effectively.
\end{abstract}

\section{Introduction}

Microwave ablation (MWA) is a way of thermal therapies. Because of its minimally invasive and highly thermal efficiency, MWA has been widely used in clinical [1], and it has become an important means of treating liver tumor $[1,2]$. The principle of microwave ablation to treat hepatocellular carcinoma is based on the microwave heating effect [3]. By ultrasound guided, the microwave antenna can directly put into the interior of the liver cancer as a heat source, till the temperature reaches the $60^{\circ} \mathrm{C}$ above, and it can kill cancer cells in situ instantaneously without damaging the healthy tissue [1]. Microwave energy is typically set at $915 \mathrm{MHz}$ or $2.45 \mathrm{GHz}$ in clinical. Because of the physical characteristics of microwave and liver blood supply characteristics, the current treatment of liver cancer is still confined to the small hepatocellular carcinoma. There are still many defects in the treatment of large hepatocellular carcinoma. It's difficult for MWA to kill the entire tumor disposable, but multiple overlapping ablation will lead to incomplete coverage [4-6]. Therefore, expanding the lesion size is the key to improve the curative effect of microwave treatment of large hepatic tumors. Many scholars researched to improve the antenna structure and a large number of experimental studies has proved that the changing antenna significantly expand the ablation zone size [5-8]. The other approach is to add liquid during microwave ablation in order to expand the lesion size. Experiments demonstrated that the perfusion of microwave antenna not only can significantly expand the scope and improve the solidification shape, also can pour anticancer drugs into tumors, cooperate with ablation to kill tumors.

This paper applied the finite element method to simulate the microwave ablation of 
adding saline or ethanol in the process, by changing the water content in the organization to expand the size of the ablation zone. Considering the flow of blood in the liver and the changes of liver thermal property parameter, we studied at different microwave power to research whether coagulation necrosis region expanded effectively. At the same time we observed the distribution of temperature field for providing clinical guidance.

\section{Materials and Method}

We used the finite element method to simulate the performance of the perfusion type of microwave ablation antenna in liver tumor. The FEM package is the COMSOL Multiphysics 5.0, and we will describe the model in detail in the follow section.

\section{Antenna Structure}

In this study, we used the monopole antenna [9] which added a water layer. The antenna is consisted by inner and outer conductors, catheter, and air column and water layer. The water layer was set in the outer catheter, and the output located at the edge of the catheter, in order to guarantee the liquid can pour into the liver tumor. As to the coaxial antenna, in the numerical simulation, we set the power input at the inner catheter between the inner and outer conductors [10]. The size of antenna structure was shown in Table 1. From Figure 1, the blue section indicates the water injection layer.

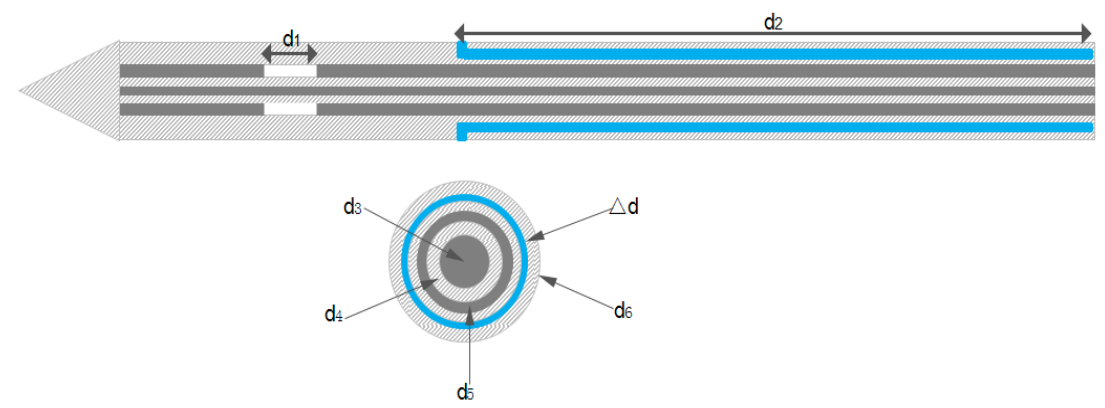

Figure.1. Configurations of antenna and the cross section of antenna

Table 1. The size of antenna structure

\begin{tabular}{ccccccc}
\hline $\mathrm{d} 1$ & $\mathrm{~d} 2$ & $\mathrm{~d} 3$ & $\mathrm{~d} 4$ & $\mathrm{~d} 5$ & $\mathrm{~d} 6$ & $\Delta \mathrm{d}$ \\
$/(\mathrm{mm})$ & $/(\mathrm{mm})$ & $/(\mathrm{mm})$ & $/(\mathrm{mm})$ & $/(\mathrm{mm})$ & $/(\mathrm{mm})$ & $/(\mathrm{mm})$ \\
\hline 2 & 40 & 0.378 & 1.172 & 1.7 & 2.7 & 0.2 \\
\hline
\end{tabular}

\section{Bio-heat Equation}

Microwave energy converted into heat when microwave ablation instrument was turned on, meanwhile, the temperature of tissue was increasing. When temperature approached or exceed $60^{\circ} \mathrm{C}$, the tumor cells produce irreversible necrosis to achieve the purpose of killing tumor. The Pennes bio-heat equation (Eq. (1)) governs heating transfer during the thermal ablation [11-12].

$$
\rho c \frac{\partial T}{\partial t}=\mathrm{k} \nabla^{2} \mathrm{~T}+\mathrm{Q}-\rho_{b 1} c_{b 1} \omega_{b 1}\left(T-T_{b 1}\right)
$$

where: $\rho$ and $\rho_{b 1}$ is the density of the tissue and the blood $\left(\mathrm{kg} / \mathrm{m}^{3}\right), \mathrm{c}$ and $\mathrm{c}_{\mathrm{b} 1}$ is the specific heat capacity of the tissue and the blood $\left(\mathrm{J} /\left(\mathrm{kg}^{\circ} \mathrm{C}\right)\right), \mathrm{k}$ is the thermal 
conductivity $\left(\mathrm{W} /\left(\mathrm{m}^{\circ} \mathrm{C}\right)\right), \mathrm{T}$ and $\mathrm{T}_{\mathrm{b} 1}$ is the temperature of the tissue and the blood $\left({ }^{\circ} \mathrm{C}\right)$, $\omega_{b 1}$ is the blood perfusion $(1 / \mathrm{s}), \mathrm{Q}$ is the resistive heating $\left(\mathrm{J} /\left(\mathrm{m}^{3} \cdot \mathrm{s}\right)\right)$ [13]. In order to approach the clinical practical, blood perfusion was not neglected in the model. The temperature distribution in the tissue was obtained by solving Pennes bio-heat equation [9].

\section{Geometric Model}

The software divided the whole geometric model into finite element automatically, and in this model, the average quality of the grid unit was over 0.8. Fig. 2 illustrates the 2-D meshed numerical model. Refined the antenna part can get the accurate temperature distribution.

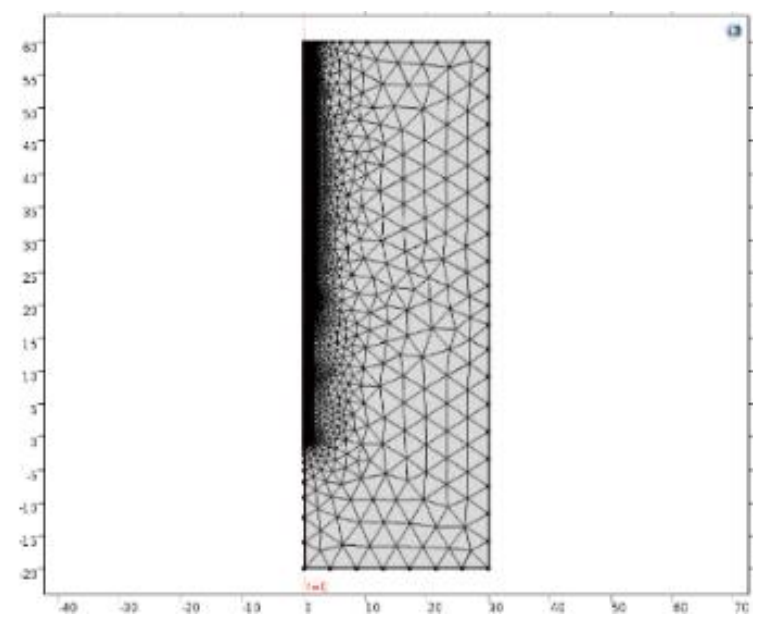

Figure. 2. 2-D meshed numerical model

\section{Numerical Setting}

In this study, some parameters and boundary conditions are set as follows:

The duration time was $300 \mathrm{~s}$ and the microwave frequency was $2.45 \mathrm{GHz}$.

The microwave power was set at $40 \mathrm{~W}, 60 \mathrm{~W}$ and $80 \mathrm{~W}$.

Liver boundary temperature was set at $37^{\circ} \mathrm{C}$, and the outer surface was truncated by a scattering boundary condition.

Due to the liquid injected during the microwave ablation process, we chose the laminar flow and the heat transfer module. And in the study, the saline or ethanol $(10 \mathrm{ml})$ was injected into the liver at the beginning 100s of the whole MWA process. So the average speed to inject the liquid was $75.8 \mathrm{~mm} / \mathrm{s}$.

The properties of liver and liquid and the antenna was shown in Tab.2 and Tab.3.

Table 2. The changing thermal properties of liver [14]

\begin{tabular}{cccc}
\hline & $\begin{array}{c}\text { Conductivity } \\
/(\mathrm{S} / \mathrm{m})\end{array}$ & $\begin{array}{c}\text { Specific heat capacity } \\
/(\mathrm{J} /(\mathrm{kg} \cdot \mathrm{K}))\end{array}$ & $\begin{array}{c}\text { Thermal conductivity } \\
/(\mathrm{W} /(\mathrm{m} \cdot \mathrm{K}))\end{array}$ \\
\hline $37-70^{\circ} \mathrm{C}$ & 1.69 & 3600 & 0.56 \\
$70-140^{\circ} \mathrm{C}$ & 1.13 & 3800 & 1.2 \\
\hline
\end{tabular}


Table 3. Properties of liver, liquid and antenna $[9,15]$

\begin{tabular}{ccccccc}
\hline & $\begin{array}{c}\text { Specific } \\
\text { heat } \\
\text { capacity } \\
/(\mathrm{J} /(\mathrm{kg} \cdot \mathrm{K}))\end{array}$ & $\begin{array}{c}\text { Thermal } \\
\text { conductivity } \\
/(\mathrm{W} /(\mathrm{m} \cdot \mathrm{K}))\end{array}$ & $\begin{array}{c}\text { Density } \\
/\left(\mathrm{kg} / \mathrm{m}^{3}\right)\end{array}$ & $\begin{array}{c}\text { Relative } \\
\text { permittivity }\end{array}$ & $\begin{array}{c}\text { Relative } \\
\text { permeability }\end{array}$ & $\begin{array}{c}\text { Conductivity } \\
/(\mathrm{S} / \mathrm{m})\end{array}$ \\
\hline Liver & - & - & 1050 & 45.6 & 1 & - \\
tissue & - & - & 1000 & - & - & - \\
Blood & 4128 & 0.6 & 998 & 78 & 1 & 1.8 \\
Saline & 4183 & 0.24 & 791 & 25.7 & 1 & $1.35 \mathrm{e}-7$ \\
Ethanol & 2440 & - & - & 1 & 1 & $5.998 \mathrm{e} 7$ \\
Copper & - & - & - & 2.1 & 1 & 0 \\
Teflon & - & & & & & \\
\hline
\end{tabular}

\section{Results and Discussion}

In MWA, when the temperature exceeds $60^{\circ} \mathrm{C}$, tumor cells dehydrated and dead immediately, so we set $60^{\circ} \mathrm{C}$ as the edge of temperature distribution [1]. The data shows as follows.

Table 4. Results at $\mathrm{P}=40 \mathrm{~W}$

\begin{tabular}{ccccc}
\hline & $\begin{array}{c}\text { Transverse } \\
\text { diameter } \\
/(\mathrm{cm})\end{array}$ & $\begin{array}{c}\text { longitudinal } \\
\text { diameter } \\
/(\mathrm{cm})\end{array}$ & $\begin{array}{c}\text { Lesion size } \\
/\left(\mathrm{cm}^{2}\right)\end{array}$ & $\begin{array}{c}\text { Temperature at } \\
\text { the slot } \\
/\left({ }^{\circ} \mathrm{C}\right)\end{array}$ \\
\hline MWA only & 1.97 & 3.80 & 6.5216 & 93 \\
Saline & 2.07 & 3.78 & 7.8010 & 94.9 \\
Ethanol & 2.05 & 3.77 & 7.4528 & 94 \\
\hline
\end{tabular}

Table 5. Results at $\mathrm{P}=60 \mathrm{~W}$

\begin{tabular}{ccccc}
\hline & $\begin{array}{c}\text { Transverse } \\
\text { diameter } \\
/(\mathrm{cm})\end{array}$ & $\begin{array}{c}\text { longitudinal } \\
\text { diameter } \\
/(\mathrm{cm})\end{array}$ & $\begin{array}{c}\text { Lesion size } \\
/\left(\mathrm{cm}^{2}\right)\end{array}$ & $\begin{array}{c}\text { Temperature at the } \\
\text { slot } \\
/\left({ }^{\circ} \mathrm{C}\right)\end{array}$ \\
\hline MWA only & 2.48 & 4.39 & 8.1664 & 113 \\
Saline & 2.59 & 4.37 & 11.588 & 116 \\
Ethanol & 2.56 & 4.39 & 11.874 & 115 \\
\hline
\end{tabular}

Table 6. Results at $\mathrm{P}=80 \mathrm{~W}$

\begin{tabular}{ccccc}
\hline & $\begin{array}{c}\text { Transverse } \\
\text { diameter } \\
/(\mathrm{cm})\end{array}$ & $\begin{array}{c}\text { longitudinal } \\
\text { diameter } /(\mathrm{cm})\end{array}$ & $\begin{array}{c}\text { Lesion size } \\
/\left(\mathrm{cm}^{2}\right)\end{array}$ & $\begin{array}{c}\text { Temperature at } \\
\text { the slot } \\
/\left({ }^{\circ} \mathrm{C}\right)\end{array}$ \\
\hline MWA only & 2.81 & 4.74 & 9.3533 & 134 \\
Saline & 2.94 & 4.77 & 15.016 & 138 \\
Ethanol & 2.91 & 4.78 & 14.843 & 137 \\
\hline
\end{tabular}

From Table4-6, at the same microwave power, the ablation area of MWA with saline or ethanol were bigger than the only MWA group. For MWA with saline group, the lesion size expanded from $19.42 \%$ to $60.54 \%$ with the increasing of the microwave power. For MWA with ethanol group, the lesion size expanded from $15.66 \%$ to $58.69 \%$ with the increasing of the microwave power. Compared with the only MWA group, the transverse diameter of the group with liquid expanded, but the longitudinal diameter did not change significantly.

Analyze the slot and the outlet of the water layer temperature rising curve when microwave ablation power was $60 \mathrm{~W}$. 


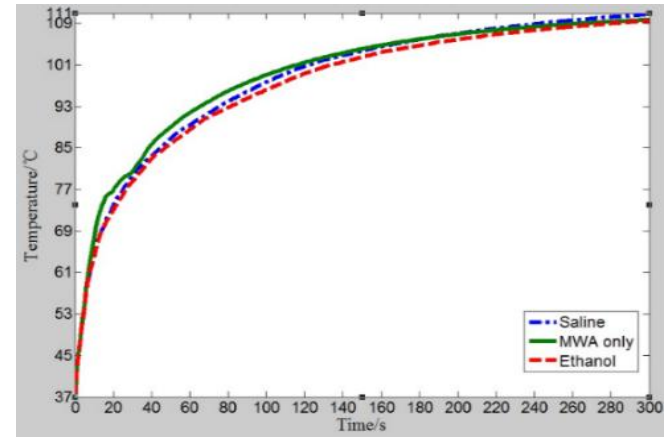

Figure.3. Slot temperature rising curve at $\mathrm{P}=60 \mathrm{~W}$

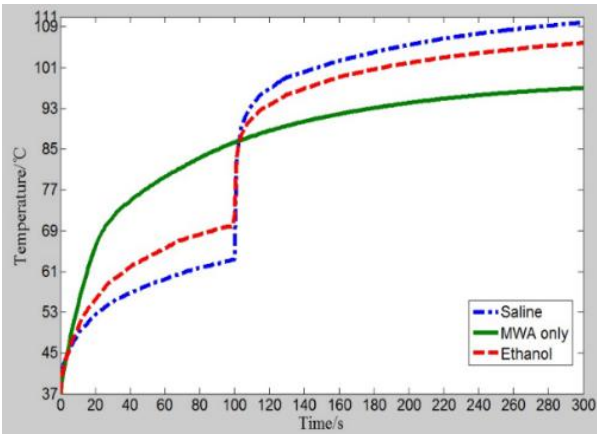

Figure.4. The outlet of the water temperature rising curve at $\mathrm{P}=60 \mathrm{~W}$

Fig. 3 shows that the temperature rising trend of the injection of saline or ethanol group is lower than of the only MWA group. From 0s to 100s, saline or ethanol was injected into the liver tumor, and the temperature of outlet was shut down compared to the only MWA group (Fig. 4). As time increasing, liquid groups' temperature was increasing, and it's higher than that in the without liquid group. At the same spot, the higher temperature shows that it spread more heat outwards, which was to cause the larger lesion size.

The liquid injection with MWA has expanded the ablation zone. Because of perfusion microwave ablation, not only increase the water content in tissue, increase the absorption of heat, but also improve the efficiency of microwave energy convert into heat. The increase of water content in tissue can also reduce the center of the microwave carbonization, in favor of the transmission of microwave.

\section{Conclusions}

This study has researched the effect of the liquid injection to the hepatic microwave ablation by using finite element method. Through the analysis of coagulation necrosis area and the slot temperature among different groups at different microwave power, we found that inject liquid can expand the lesion size significantly. Compared with the only MWA group, the lesion size of the saline group expanded from $19.42 \%$ to $60.54 \%$, and the ethanol group expanded from $15.66 \%$ to $58.69 \%$ with the increasing of the microwave power. And the temperature rising trend of the outlet at the water layer, the liquid injection groups increased slower than the only MWA group.

Study has some limits. In this study, we set the liver as the tissue to calculate. In fact, liver can be seen as porous media to simulate, and the liquid flow can be seen as seepage by using Darcy's Law. It will be much more accurate to the clinical practical. So this condition will be taken into account in our further work.

\section{Acknowledgements}

This research is supported by Beijing Natural Science Foundation (3162006), National Science Foundation of China (No. 31070754), Beijing Municipal Commission of Education Project Scientific and Technological Program (KM201410005028), the Importation and Development of High-Caliber Talents Project of Beijing Municipal Institutions and Basic Research Foundation of Beijing University of Technology (X4015999201401). The author thanks Prof. Nan for her favorable advice and kind guidance. 


\section{References}

[1] Dong B, Liang P, Yu X, et a1. Percutaneous sonographically guided microwave coagulation therapy for hepatocellular carcinoma: results in 234 patients, AJR Am J Roentgenol, 180, 1547(2003).

[2] S.N.Goldberg, Ahmed M. Minimally invasive image-guided therapies for hepatocellular carcinoma, Journal of Clinical Gastroenterology, 35, S115 (2002).

[3] Yang WZ, Jiang N, Huang N, et al. Combined therapy with transcatheter arterial chemoembolization and percutaneous microwave coagulation for small hepatocellular carcinoma, World J Gastroenterol, 15,748(2009).

[4] Yang L, Wen R, Qin J, et al. A robotic system for overlapping radiofrequency ablation in large tumor treatment, Mechatronics, 15,887(2010).

[5] A.Sanpanich, Y.Kajornpredanon, P.Phasukkit, et al. Opened-tip applicator and ex vivo experimental results for microwave breast cancer ablation, in Proc. IEEE Antennas and Propagation (APCAP),(Singapore,2012).

[6] J.Chiang, K.A.Hynes, M.Bedoya, et al. A Dual-Slot Microwave Antenna for More Spherical Ablation Zones: Ex Vivo and in Vivo Validation, Radiology, 268,382(2013).

[7] S.Maini, A.Marwaha. Design and performance analysis of multisection floating sleeve antenna using FEM for interstitial microwave ablation for HCC, in Proc. IEEE Point-of-Care Healthcare Technologies (PHT), (Bangalore, India, 2013).

[8] H.Luyen, S.C.Hagness, N.Behdad. A Balun-Free Helical Antenna for Minimally Invasive Microwave Ablation, IEEE Transactions on Antennas \& Propagation, 63,959(2015).

[9] M.Chaichanyut. Microwave ablation with cap-choke antenna: Result in computer simulation, in Proc. IEEE Electrical Engineering/Electronics Computer Telecommunications and Information Technology (ECTI-CON), (Chumphon, Thailand, 2010).

[10] Nan Q, Fei Z, Guo X M. Study on the Temperature Field of the Endocardial Point-by-point Microwave Ablation of Atrial Fibrillation, Journal of Beijing University of Technology, 40,1579(2014).

[11] H.H.Pennes. Analysis of tissue and arterial blood temperatures in the resting human forearm. 1948, Journal of Applied Physiology, 1, 93(1948).

[12] Zhai F, Nan Q, Zhang H J, et al. The Comparison of Two Simulation Methods on the Thermal Ablation with Large Blood Vessel, Applied Mechanics \& Materials, 444, 1177(2013).

[13] P.Punit, M.C.Converse, J.G.Webster, et al. An optimal sliding choke antenna for hepatic microwave ablation, Biomedical Engineering IEEE Transactions on, 56, 2470(2009). 
[14] Shui-Cai WU, Zhao L, Gao H J. Study of the Effect and Simulation of Water Vaporization in Tissues on Temperature Distribution in Microwave Hyperthermia, Journal of Beijing University of Technology, 55,437(2011).

[15] C.L.Brace, P.F.Laeseke, V.Prasad, et al. Electrical isolation during radiofrequency ablation: 5\% dextrose in water provides better protection than saline, in Conf Proc. IEEE Eng Med Biol Soc, (New York City, USA, 2006). 